\title{
Immunohistochemical Demonstration of Somatostatin-Containing Cells in the Human, Dog and Rat Thyroids
}

\author{
Yukio Yamada, Seiki Ito, Yohichi Matsubara* and \\ Shigeru Kobayashi $\dagger$ \\ The First Department of Internal Medicine, *The First \\ Department of Surgery and tThe Third Department of \\ Anatomy, Niigata University School of Medicine, Niigata
}

\begin{abstract}
Yamada, Y., Ito, S., Matsubara, Y. and Kobayashr, S. Immunohistochemical Demonstration of Somatostatin-Containing Cells in the Human, Dog and Rat Thyroids. Tohoku J. exp. Med., 1977, 122 (1), 87-92 — By an indirect immunofluorescence technique using the somatostatin antibody, somatostatincontaining cells were demonstrated to exist in the human, dog and rat thyroids. These cells were located predominantly in the interfollicular areas and more scatteringly in the follicular areas. The source of these somatostatin-containing cells was discussed. —_ somatostatin; thyroid; immunofluorescence technique; parafollicular cells
\end{abstract}

Somatostatin (growth hormone release-inhibiting hormone) was originally isolated from the ovine hypothalamus (Brazeau et al. 1973), later characterized (Burgus et al. 1973) and then synthesized (Rivier et al. 1973). Both natural and synthetic somatostatin preparations inhibit not only the release of growth hormone (GH) (Brazeau et al. 1973; Lovinger et al. 1973; Siler et al. 1973; Vale et al. 1972, 1974) but also the release of thyrotropin (TSH) (Hall et al. 1973; Siler et al. 1973; Vale et al. 1974) from the pituitary gland. Furthermore, somatostatin also suppresses the release of extrapituitary hormones such as insulin, glucagon (Alberti et al. 1973; Alford et al. 1974; Koerker et al. 1974; Mortimer et al. 1974; Sakurai et al. 1974; Yen et al. 1974) and gastrin (Bloom et al. 1974).

In addition to the studies on the physiological effects of somatostatin mentioned above, Arimura et al. (1975a) prepared antibodies to this substance and this advance has allowed immunohistochemical and radioimmunoassay methods to be employed for the search of localization of somatostatin in tissues; it is demonstrable not only in the central nervous system (Hökfelt et al. 1974, 1975; Pelletier et al. 1974; Dubois et al. 1975a; King et al. 1975; Brownstein et al. 1975; Alpert et al. 1976), but also in the endocrine pancreas and the gastro-intestinal tract (Luft et al. 1974; Dubois 1975; Dubois et al. 1975b; Polak et al. 1975; Arimura et al. 1975b). Furthermore, Hökfelt et al. (1975) have recently demonstrated with fluorescent histochemistry the occurrence of somatostatin-containing cells in the rat thyroid.

Received for publication, December 4, 1976. 
Although this report suggested the existence of somatostatin-containing cells in the thyroid of many mammals including human, the proof remained to be obtained.

In this study we demonstrate, by the indirect immunofluorescence technique, the occurrence of somatostatin-containing cells in the thyroid of the human, dog and rat.

\section{Materials and Methods}

\section{Antibody preparation}

Somatostatin antibody. Synthetic somatostatin (Peptide Institute Research Foundation, Osaka, Japan) used as the antigen was coupled with bovine serum albumin (BSA) by the use of glutaraldehyde. The somatostatin-BSA complex was emulsified with complete Freund's adjuvant and injected into rabbits subcutaneously at intervals of 30-40 days.

Immunofluorescent agents. Flouresecein isothionate (FITC)-conjugated anti-rabbit IgG goat serum (Miles, England) was used.

\section{Tissue preparation}

Fresh thyroids were removed from the human, dog and rat, and small blocks were fixed in Bouin's solution at room temperature for $3 \mathrm{hr}$. Then they were dehydrated and embedded in paraffin wax (melting point $42-44^{\circ} \mathrm{C}$ ). Sections were cut $(5 \mu \mathrm{m}$ thick) and fixed on glass slides treated with a mixture of $0.5 \%$ gelatin and $0.05 \%$ chromium sulfate.

\section{Immunofluorescence}

After removal of paraffin wax with xylene, a drop of somatostatin antibody diluted $1: 20$ with a phosphate-buffered saline solution (PBS, pH 7.4, 0.05 M) was applied to each section, which was then incubated for $2 \mathrm{hr}$ at $37^{\circ} \mathrm{C}$ in a moist chamber. All the sections were then washed in the buffer described above, and anti-rabbit IgG serum-FITC diluted with PBS was applied to them before they were again incubated for $1 \mathrm{hr}$ at $37^{\circ} \mathrm{C}$ in a moist chamber.

\section{Control study}

As controls for somatostatin antibody specificity, either $1: 20$ dilution of normal rabbit serum or 1:20 dilution of somatostatin antibody absorbed with $500 \mu \mathrm{g}$ of synthetic somatostatin, $100 \mu \mathrm{g}$ of thyroxine, $100 \mu \mathrm{g}$ of triidothyronine or $100 \mu \mathrm{g}$ of porcine calcitonin per $\mathrm{ml}$ of undiluted antibody was substituted for the specific antibody in the staining procedure.

\section{Results}

Somatostatin-containing cells were found in the human (Fig. 1), dog (Figs. 2, 3) and rat (Fig. 4) thyroids, although the number of them was rather limited. of the three mammalian thyroids, the human thyroid was provided with less numerous somatostatin-containing cells than the others (Fig. 1). In all cases, somatostatincontaining cells were predominantly located in the parafollicular areas although scattered cells were also seen in the follicular areas (Fig. 3). Somatostatin-containing cells were oval, round or polygonal in shape, with strongly and homogeneously fluorescent cytoplasms and large non-fluorescent central nuclei. After incubation with somatostatin antibody absorbed with thyroxine, triidothyronine or porcine calcitonin, immunofluorescent cells could still be seen. On the other hand, they 


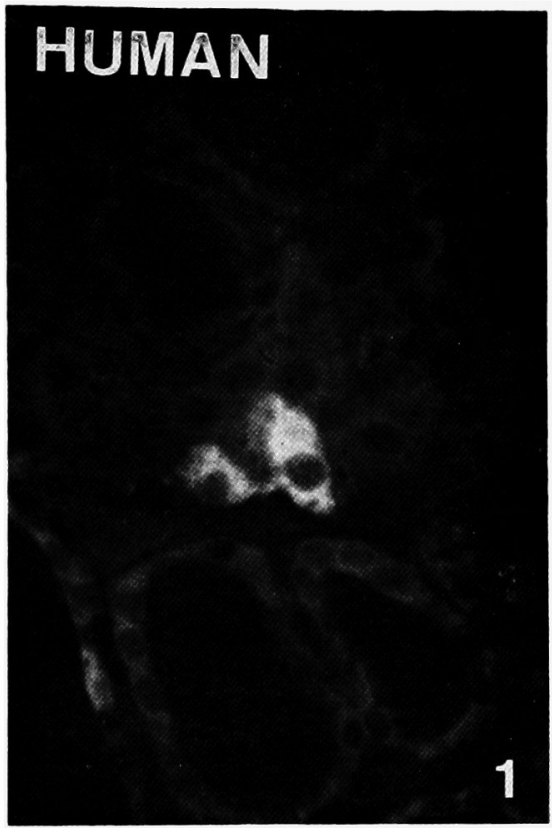

Fig. 1. Immunofluorescence micorgraph of the human thyroid after incubation with somatostatin antibody. Somatostatin-containing cells are seen in the interfollicular position.

\section{DOG}

\section{DOG}
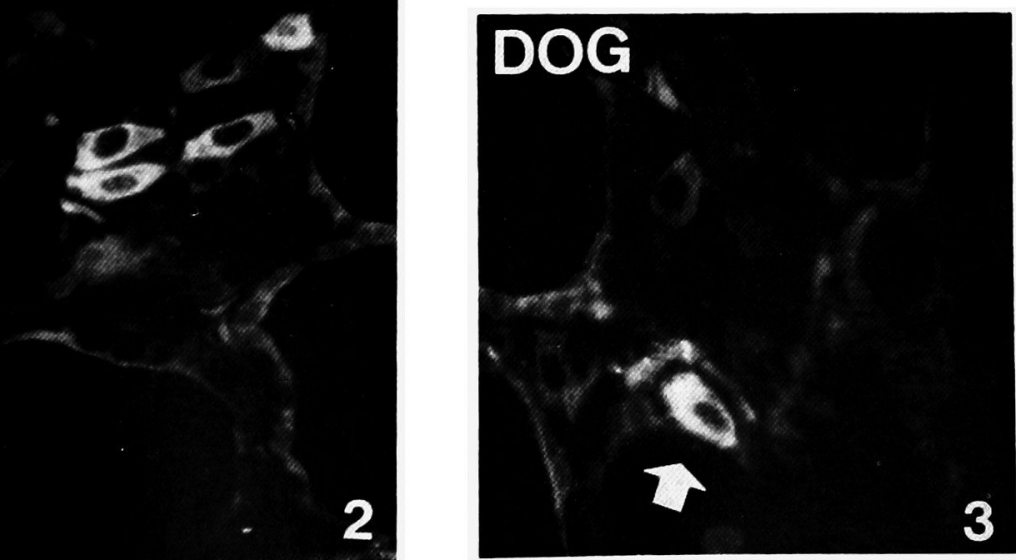

Figs. 2 and 3. Immunofluorescence micrographs of the dog thyroid after incubation with somatostatin antibody. Somatostatin-containing cells are situated in the interfollicular (Fig. 2) and the follicular (Fig 3, arrow) positions. 


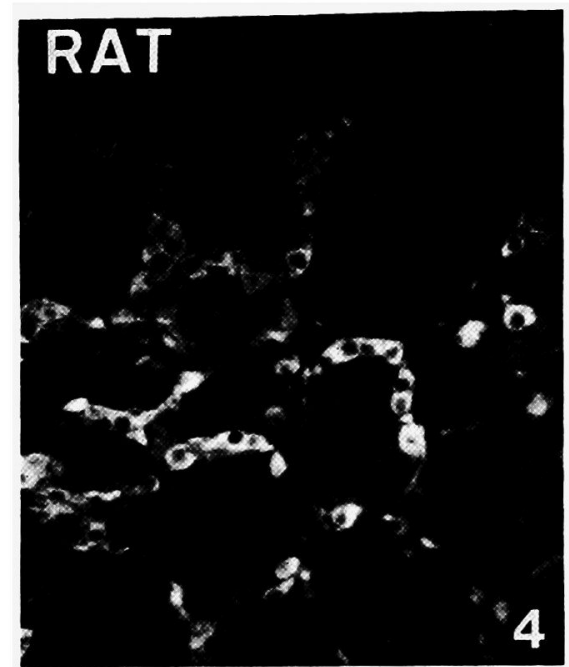

Fig. 4. Immunofluorescence micrograph of the rat thyroid after incubation with somatostation antibody. Somatostatin-containing cells are seen in the interfollicular position.

were not detected after incubation with somatostatin antibody absorbed with synthetic somatostatin. These immunocytological reactions, therefore, were best explained by proposing that these cells contained somatostatin or somatostatin-like substances.

\section{Discussion}

The present study demonstrates the occurrence of cells reacting with somatostatin antibody in the human, dog and rat thyroids. These results give immunohistochemical evidence for the presence of somatostatin, a hypothalamic tetradecapeptide, in the thyroid of mammals including human. These positive cells are distributed both in the interfollicular and in the follicular areas. This result agrees to an observation of Hökfelt et al. (1975) in the rat thyroid.

Now, it is known that in addition to the principal cells (epithelial or glandular cells) of the thyroid follicles, there is another small population of cells which are distributed in the follicular epithelium and interfollicular areas. The latter has commonly been called "parafollicular cells" and also referred to as "mitochondrionrich cells" or "C cells" (Nonidez 1931/1932). They arise from cells in the epithelium and gradually withdraw into the interfollicular areas, so that many of the parafollicular cells are interfollicular in position (Bloom and Fawcett 1968). It was also established by immunofluorescence using the calcitonin antibody (Bussolati and Pearse 1967) that the parafollicular cells of the thryoid are the source of calcitonin. From the fact that the localization of somatostatin-containing cells in the thyroid well corresponds to that of parafollicular cells, it seems likely that the somatostatin-containing cells, as well as the calcitonin-containing cells, belong to the parafollicular cells. 


\section{References}

1) Alberti, K.G.M.M., Christensen, N.J., Christensen, S.E., Hansen, A.P., Iversen, J., Lundbaek, K., Seyer-Hansen, K. \& Orskov, H. (1973) Inhibition of insulin secretion by somatostatin. Lancet, 2, 1299-1301.

2) Alford, F.P., Bloom, S.R., Mabarro, J.D.N., Hall, R., Besser, G.M., Coy, D.H., Kastin, A.J. \& Schally, A.V. (1974) Glucagon control of fasting glucose in man. Lancet, 2, 974-977.

3) Alpert, L.C., Brawer, J.R., Pater, Y.C. \& Reichlin, S. (1976) Somatostatinergic neurons in anterior hypothalamus: Immunohistochemical localization. Endocrinology, 98, 255-258.

4) Arimura, A., Sato, H., Coy, D.H. \& Schally, A.V. (1975a) Radioimmunoassay for GH-release inhibiting hormone. Proc. Soc. exp. Biol. Med. (N.Y.), 148, 784-789.

5) Arimura, A., Sato, H., Dupont, A., Nishi, N. \& Schally, A.V. (1975b) Somatostatin: Abundance of immunoreactive hormone in the rat stomach and pancreas. Science, 189, $1007-1009$.

6) Bloom, W. \& Fawcett, D.W. (1968) A Ttextbook of Histology. 9th Edition, W.B. Saunder Company, Philadelphia-London-Tronto, p. 445.

7) Bloom, S.R., Mortimer, C.H., Thorner, M.O., Besser, G.M., Hall, R., Gomez-Pan, A., Roy, V.M., Russel, R.C.G., Coy, D.H., Kastin, A. \& Schally, A.V. (1974) Inhibition of gastrin and gastric acid secretion by growth-hormone release-inhibiting hormone. Lancet, 2, 1106-1109.

8) Brazeau, P., Vale, W., Burgus, R., Ling, N., Butcher, M., Rivier, J. \& Guillemin, R. (1973) Hypothalamic polypeptide that inhibits the secretion of immunoreactive growth hormone. Science, 179, 77-79.

9) Brazeau, P., Rivier, J., Vale, W. \& Guillemin, R. (1974) Inhibition of growth hormone secretion in the rat by synthetic somatostatin. Endocrinology, 94, 184-187.

10) Brownstein, M., Arimura, A., Sato, H., Schally, A.V. \& Kizer, J.S. (1975) The regional distribution of somatostatin in the rat barin. Endocrinology, 96, 1456-1461.

11) Burgus, R., Ling, N., Butcher, M. \& Guillemin, R. (1973) Primary structure of somatostatin, a hypothalamic peptide that inhibits the secretion of pituitary growth hormone. Proc. nat. Acad. Sci. USA, 70, 684-688.

12) Bussolati, G. \& Pearse, A.G.E. (1967) Immunofluorescence localization of calcitonin in the C-cells of pig and dog's thyroid. J. Endocr., 37, 205-209.

13) Dubois, M.P. (1975) Immunoreactive somatostatin is present in discrete cells of the endocrine pancreas. Proc. nat. Acad. Sci. USA, 72, 1340-1343.

14) Dubois, P.M., Barry, J. \& Leonardelli, J. (1975a) Mise en evidence par immunofluorescence et repartition de la somatostatin (SRIF) dans l'eminence mediane de vertebres. C.R.H. Acad. Sci., (Ser. D), 279, $1895-1903$.

15) Dubois, P.M., Paulin, C., Assan, R. \& Dubois, M.P. (1975b) Evidence for immunoreactive somatostatin in the endocrine cells of human feotal pancreas. Nature (Lond.), 256, 731-732.

16) Hall, R., Besser, G.M., Schally, A.V., Coy, D.H., Evered, D., Golodie, D.J., Kastin, A.J., McNeilly, A.S., Mortimer, C.H., Phenekos, C., Tunbridge, W.M.G. \& Weightman, D. (1973) Action of growth-hormone-release inhibitory hormone in healthy men and in acromegaly. Lancet, 2, 581-584.

17) Hökfelt, T., Effendic, S., Johansson, O., Luft, R. \& Arimura, A. (1974) Immunohistochemical localization of somatostatin (growth hormone release-inhibiting factor) in the guinea pig brain. Brain Res., 80, 165-169.

18) Hökfelt, T., Effendic, S., Hellerström, C., Johansson, O., Luft, R. \& Arimura, A. (1975) Cellular location of somatostatin in endocrine-like cells and neurons of the rat with specific references to the A-cells of the pancreatic islets and to the hypothalamus. Acta endocr., 80, Suppl. 200, 1-40.

19) King, J.C., Gerall, A.A., Fishback, J.B., Elkind, K.E. \& Arimura, A. (1975) Growth hormone-release inhibiting hormone ( $\mathrm{GH}-\mathrm{RIH})$ pathway of the rat hypothalamus revealed by the unlabeled antibody peroxidase-antiperoxidase method. Cell Tiss. 
Res., 160, 423-430.

20) Koerker, D.J., Ruch, W., Chideckel, E., Palmer, J., Goodner, C.J., Ensinek, J. \& Gale, C.C. (1974) Somatostatin, hypothalamic inhibitor of the endocrine pancreas. Science, 184, 482-483.

21) Lovinger, R., Boryzcka, A.T., Shackeflord, R., Kaplan, S.L., Ganong, W.F. \& Grumbach, M.M. (1974) Effect of synthetic somatotrophin release inhibiting factor on the increase in plasma growth hormone elicited by L-dopa in the dog. Endocrinology, 95, 943-946.

22) Luft, R, Effendic, S., Hökflet, T., Johansson, O. \& Arimura, A. (1974) Immunohistochemical evidence for the localization of somatostatin-like immunoreactivity in a cell population of the pancreatic islets. Med. Biol., 52, 428-430.

23) Mortimer, C.H., Tarnbridge, W.M.G., Carr, D., Yeomons, L., Lind, T., Coy, D.H., Bloom, S.R., Kastin, A., Mallinson, C.N., Besser, G.M., Schally, AlV. \& Hall, R. (1974) Effects of growth-hormone release-inhibiting phormone on circulating glucagon, insulin and growth hormone in normal, diabetic, acromegalic and hypopituitary patients. Lancet, 1, 697-701.

24) Nonidez, J.F. (1931/1932) The origin of the parafollicular cells, a second epithelial component of the thyroid gland of the dog. Amer. J. Anat. 49, 479-495.

25) Pelletier, G., Labrie, F., Arimura, A. \& Schally, A.V. (1974) Electron microscopic immunohistochemical localization of growth hormone-release inhibiting hormone (somatostatin) in the rat median eminence. Amer. J. Anat., 140, 445-450.

26) Polak, J.M., Pearse, A.G.E., Glimelius, L., Bloom, S.R. \& Arimura, A. (1975) Growth-hormone release-inhibiting hormone in gastro-intestinal and pancreatic D cells. Lancet, 1, 1220-1222.

27) Rivier, J., Brazeau, P., Vale, W., Ling, N., Brugus, R., Gilon, C., Yardley, J. \& Guillemin, R. (1973) Synthese totale par phase solide d'um tetradecapeptide ayant les proprietes chimiques et biologiques de la somatostatin. C.R. Acad. Sci., (Ser. D), 276, 2737-2740.

28) Sakurai, H., Dobbs, R \& Unger, R.H. (1974) Somatostatin-induced changes in insulin and glucagon secretion in normal and diabetic dogs. J. clin. Invest., 54, 13951402.

29) Siler, T.M., VandenBerg, G., Yen, S.S.C., Brazeau, P., Vale, W. \& Guillemin, R. (1973) Inhibition of growth hormone release in humans by somatostatin. $J$. clin. Endocr., 37, 632-634.

30) Vale, W., Brazeau, P., Grant, G., Nussey, A., Burgus, R., Rivier, J., Ling, N. \& Guillemin, R. (1972) Premieres observation sur le mode d'action de la somatostatin, un facteur hypothalamique qui inhibe la secretion de l'hormone de croissance. C.R. Acad. Sci., (Ser. D), 275, 2913-2915.

31) Vale, W., Rivier, C., Brazeau, P. \& Guillemin, R. (1974) Effects of somatostatin on the secretion of thyrotropin and prolactin. Endocrinology, 95, 968-977.

32) Yen, S.S.C., Siler, T.M. \& DeVane, W. (1974) Effect of somatostatin in patients with acromegaly. Supression of growth hormone, prolactin, insulin and glucose levels. New Engl. J. Med., 290, 935-938. 